\title{
YELLOWSTONE RAPTOR INITIATIVE
}

\author{
$-2$ \\ $\uparrow$ \\ DOUGLAS SMITH $\prec$ KATY DUFFY $\uparrow$ YELLOWSTONE NATIONAL PARK $\uparrow$ MAMMOTH \\ JOEL E. (JEEP) PAGEL $\prec$ U.S. FISH AND WILDLIFE SERVICE $\downarrow$ JACKSON
}

\begin{abstract}
$\uparrow \quad$ Abstract
During 2010, the Yellowstone Raptor Initiative (YRI) used grant funds from the NPS Research Station-Wyoming to create a program with a raptor-centric focus. This program, in its infancy, concentrated on involving park visitors and staff in obtaining and collating raptor sightings in Yellowstone National Park. The funds also helped locate what may be a significant raptor migration corridor through Hayden Valley, as noted via the documentation of concentrations of Swainson's Hawks on their flight through Yellowstone National Park to Argentina. Park staff and visitors attended raptor ecology and identification programs presented during the summer and fall, while a pilot ranger-led hawkwatch in Hayden Valley attracted 160 attendees, including area residents, park staff and park visitors. The Yellowstone Raptor Initiative also conducted additional outreach by presenting technical papers at the Raptor Research Foundation annual meeting regarding the YRI, and scientific work which had been accomplished by the Initiative's participating agencies and biologists during the 2010 funding year.
\end{abstract}

\section{$\downarrow$ INTRODUCTION}

Raptors in Yellowstone National Park (YNP) received initial recognition via Theodore Roosevelt's sighting of Peregrine Falcon, Merlin, and Golden Eagle during his September 1890 visit (Robinson 1921). These historic sightings, including comments by his daughter that the Golden Eagle was one of the amateur ornithologist's and future president's favorite birds, have led us to some of our current knowledge of birds of prey in Yellowstone National Park. Mr. Roosevelt's appreciation of raptors, and the notes he and his daughter have detailed have been transferred into substantive contemporary scientific and layperson observations of peregrine falcons, osprey, and bald eagles.

Birds of prey are often observed daily within YNP by visitors and staff. Raptor sightings contribute to a visitor's experience of the wildness of the Park, whether it is an adult Bald Eagle on Yellowstone Lake, a glimpse of a Peregrine Falcon flying near Yellowstone Falls, or a Great Gray Owl perched in twilight on a snag within easy viewing distance on many of the Park Service roadways and trails.

Raptors are a significant ecological component of the YNP Ecosystem. While terrestrial predators such as grizzly bears, wolves and coyotes serve as keystone species in YNP, the landscape-scale effects attributed to them do not encompass the aerial niche held by raptors. Awareness of raptors as an ecosystem driver is only now being perceived in other habitats. Their contribution as a primary or secondary contributor to top down trophic cascades and ecological functioning of Yellowstone ecosystem has been rarely studied in scientific detail.

To date, the Park's past program on raptors has been limited to projects such as the peregrine falcon reintroduction and recovery efforts cooperatively advanced with the state of Wyoming and private organizations. Other efforts led by YNP have included observation of osprey and Bald Eagles at Yellowstone Lake, and protection of an oft viewed Bald Eagle nest site near the west entrance to the Park above the Madison River.

Raptors also provide a window into the current state of the Greater Yellowstone Ecosystem. Raptors, because of their place as an upper trophic level species, serve as toxicological and ecological 
indicators of organochlorine contaminants, climate change, ecosystem shifts, trophic cascades, and prey presence and availability. Their role in the Yellowstone ecosystem is integral and unparalleled.

\section{YELLOWSTONE RAPTOR INITIATIVE}

The idea for the Yellowstone Raptor Initiative (YRI) stems from the fact that raptors are abundant in YNP, yet historically the YNP bird program only quantitatively monitored peregrine falcons, bald eagles, and ospreys, thus the objective here was to expand raptor monitoring for breeding and non-breeding seasons. A pilot project in 2010, the subject of this report, was funded by the University of Wyoming National Park Research Station.

\section{Purpose}

Objectives were to expand inventory and monitoring of raptors, emphasizing species other than those already monitored, using park staff and visitors (a form of citizen science). The vision is five years beginning with diurnal raptors and later including nocturnal raptors (owls) in year three as funding and cooperators become available. Public involvement (scientists and laypeople) and education are centerpieces of the program.

\section{Products}

Via the Yellowstone Raptor Initiative, we originally proposed to augment inventory of Bald Eagle, Peregrine Falcon and Osprey, begin monitoring common ones (Red-tailed Hawks, Swainson's Hawks, American Kestrel), improve visitor identification of raptors, and sporadically watch a migration route. In 2010, YRI exceeded these proposed expectations with the following products:

- Submitted Scientific reports

○ Baril et al. 2009. 2009 Annual bird program report. Yellowstone National Park.

○ Baril et al. 2010. 2010 Annual bird program report. Yellowstone National Park.

- Pagel 2009. Peregrine falcons in Yellowstone National Park. USFWS report submitted to Yellowstone National Park.
- Presented papers at the International Raptor Research foundation meeting, Sept. 2010:

○ Pagel, Baril, Smith and Duffy. Peregrine Falcons (Falco peregrinus) in Yellowstone National Park; from Theodore Roosevelt to the present day. Raptor Research Foundation annual meeting, Sept. 2010.

- Smith, Pagel, and Duffy. The Yellowstone Raptor Initiative; an open call for cooperators in the vein of Theodore Roosevelt. Raptor Research Foundation annual meeting, Sept. 2010.

- Paper in preparation for peer reviewed publication: Pagel, Smith, and Schmitt. In Prep. American Martin (Martes americana) within Peregrine Falcon (Falco peregrinus) prey remains in Yellowstone National Park. Prepared for Journal of Raptor Research.

- Solicitation of professional raptor researcher involvement for the 2011 and 2012 field season efforts (published in Raptor Research Foundation's Wingspan March 2011).

- Developed professional partnerships with noted Golden Eagle, Red-tailed Hawk, Swainson's Hawk, and Raptor Migration experts.

- Developed an active outreach to the raptor research, university, and Hawkwatch communities to invite their participation to plan and implement work in YNP and the GYE.

- Conducted public raptor identification and ecology programs during summer and fall. Conducted a pilot, ranger-led, hawkwatch in Hayden Valley on September 18, 2010.

- Inventoried select back-country areas to locate active peregrine falcon nests. This augmented the 26 nests re-discovered by park staff in 2009.

- Entered select peregrine falcon nests to collect eggshell samples and for analysis of contaminants and collection of remains to determine prey utilization. 
- Trained YNP interpreters and YNP partners/collaborators on raptor ecology and biology for dissemination to the public.

- Developed a park-wide sighting record and concurrent database to record all reported observations by staff and visitors.

- Developed an identification guide for raptors found in Yellowstone during summer. This guide was available for use by visitors and staff in six park visitor centers. (See Appendix 1).

- Developed a pilot autumn raptor monitoring sampling strategy, and followed through by locating a previously unknown raptor migration corridor through YNP for Swainson's Hawks.

- Developed a pilot annual census of randomstratified blocks of habitat within the park to gain a statistically valid metric of raptor nesting occupancy.

- Prepared a synopsis of recommended approaches to develop a YNP Raptor Program that may be instituted within 5 years or less.

- Obtained significant donor contribution which serves as additional 'seed' money for the 2011 field season for the Yellowstone Raptor Initiative.

\section{$\downarrow \quad$ PUblic INVOLVEMENT}

Yellowstone National Park is one of the most visited in the National Park system with 3.5 million visitors recorded in 2010. During their visits, the public often stops at visitor centers, attends a ranger-led presentation or interpretive walk, travels around the park in private or concessionaire vehicles, or hikes on the many trails throughout the 20 million acres of the park.

Observation of raptors affords visitors an experience which they may take away from the park and apply to their own backyard; no matter where they live, raptors will be present. These experiences at their home communities may include observations of the now ubiquitous urban Peregrine Falcon or Cooper's Hawk, as well as multiple species of kestrels, Imperial Eagles, Andean Condors, Western Red-footed Falcons, etc., on other continents.

The YRI recorded several hundred data sheets from visitors reporting numerous species of raptors. These observations ranged from documenting precise nest site locations replete with age estimates of young, to general observations of raptors flying at different locations within the park boundaries. All results were entered into the GIS database to help us understand where observers saw raptors.

There were several ranger-led programs on raptors ecology and identification during summer and fall. Duffy led a pilot public hawkwatch in Hayden Valley during fall migration during which 160 visitors, local residents and staff observed migrating raptors in Hayden Valley (Figure $1 \mathrm{a}, \mathrm{b}$ ) All visitors at this event observed raptors (mostly Swainsons Hawks) migrating through Hayden Valley.

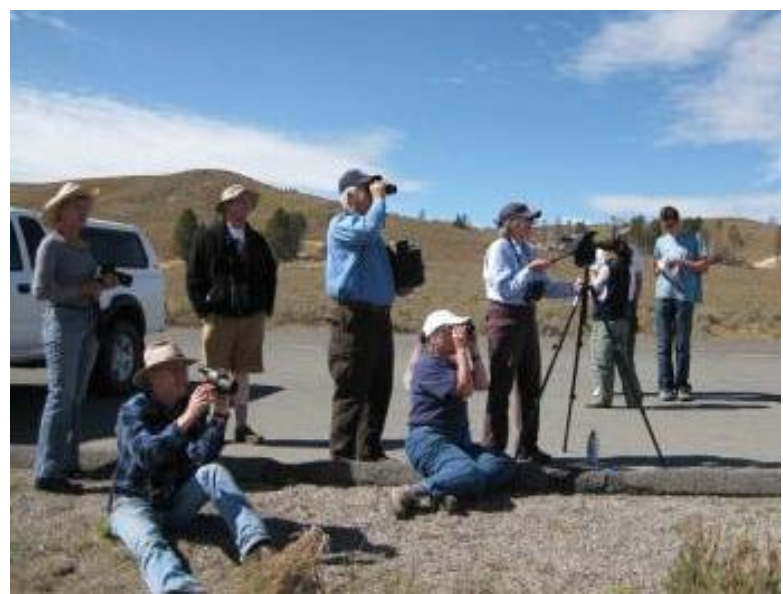

Figure 1a. Hayden Valley raptor observation day in Yellowstone National Park

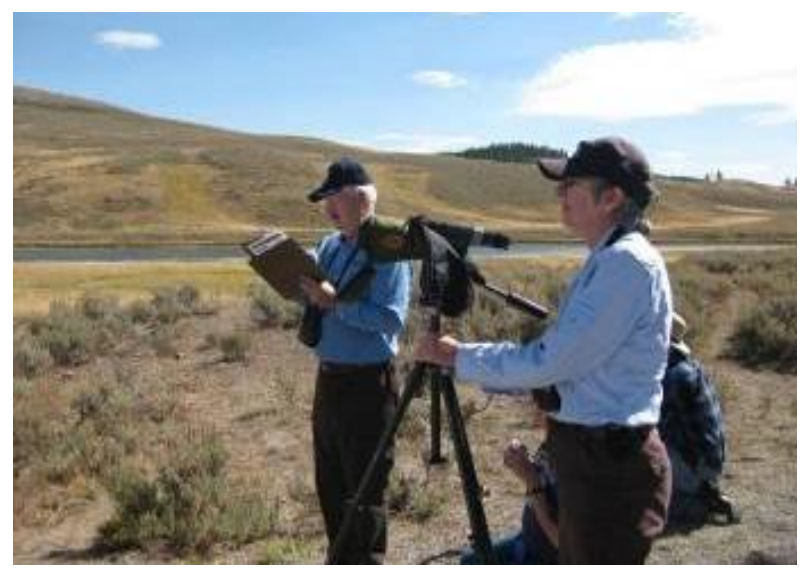

Figure 1b. Hayden Valley Raptor Observation day in Yellowstone National Park. 


\section{Yellowstone National Park Peregrine Falcon}

During August and September 2010, eight Peregrine Falcon nest ledges were entered as part of an interagency cooperative venture between the U.S. National Park Service and raptor technical expert from the U.S. Fish and Wildlife Service. Nest entries were used to collect scientific samples following the confirmed failure, or successful nesting of Peregrine Falcons during the 2010 nesting season (Figure 2). Some samples from 2009 were also detected, and collected. Samples included:

a) Remnants of peregrine falcon eggshell fragments that were used to gauge current contamination by DDT/DDE, and

b) Prey remains used to ascertain the diet of YNP peregrine falcons.

Standard measurements (useable length and width) of the nest ledge were recorded, in addition to opportunistically collecting molted Peregrine Falcon feathers. All peregrine feathers were curated for potential future isotope, contaminant, and DNA analysis.

Nest sites and nest ledges entered were selected using the following parameters:

1) Line of descent out of direct view or not easily seen by members of the public,

2) The cliff-top was easily accessible,

3) The situation (rock-type, tie-off, weather, visibility, etc.) contributed to overall safety of the bio-climber and peregrine falcons.

All nest ledges were entered after the peregrines had fledged, or long after their known nest failure (Figure 3,4). The longest approach hike to the cliff-top was approximately 3.0 hours from the vehicle to the cliff-top. Safety to the birds and bioclimber were paramount considerations prior to and during all nest entries.

Nest entries occurred in early August 2010, with additional entries occurring in mid September 2010. Two nest ledges were entered during both time periods; either to collect additional data or because the initial attempt was thwarted by lack of a static line of sufficient length. All nest ledges targeted for this project were entered.

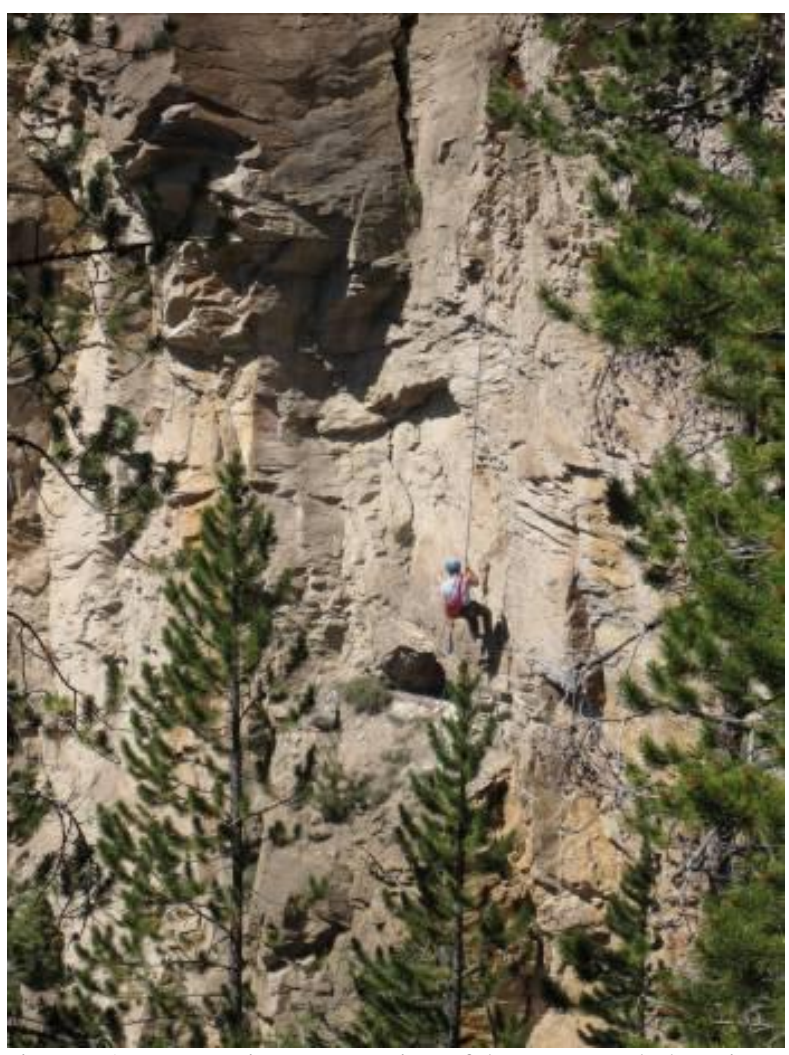

Figure 2. Entry into peregrine falcon nest ledge in Yellowstone National Park

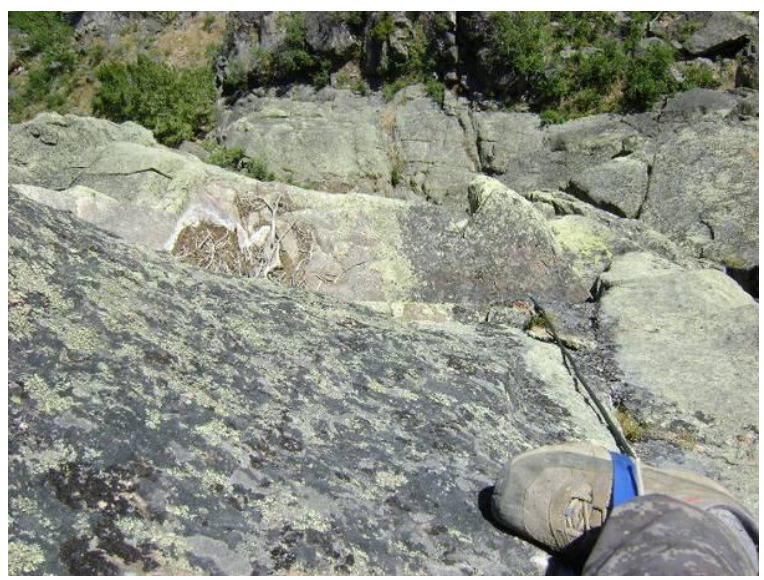

Figure 3. Entry into Peregrine Falcon nest location in Yellowstone National Park

In addition to the nest entries, the historic Peregrine Falcon hack box at Slough Creek (YNP-E004) was found to be dilapidated, and was removed from public view. It was broken down and stored on the nest ledge for eventual removal and potential use as a display in Yellowstone National Park reflecting the history of the role of the National Park Service in Peregrine Falcon population resurgence and recovery. 
Standard nest entry procedures were used to obtain samples (Pagel and Thorstrom 2007) and provide safe climbing conditions (Figure 2, 3, 4) Nests were accessed using modified rock climbing techniques. Eggshell fragments and /or egg remnants of at least 10 fragments per nest ledge were collected using forceps and I-Chem ${ }^{\circledR}$ collecting jars; all samples were measured using a digital gauge (no tapping), and were contrasted to the mechanical gauge technique (Figure 5, 6). No addled eggs were collected. Prey remains were placed into a sampling bag; not all feathers were removed from the ledge, but were sampled to obtain overall diversity of the prey from that site. All samples were curated at the Western Foundation of Vertebrate Zoology. Standard ledge measurements were recorded, and digital photographs were taken at each nest ledge.

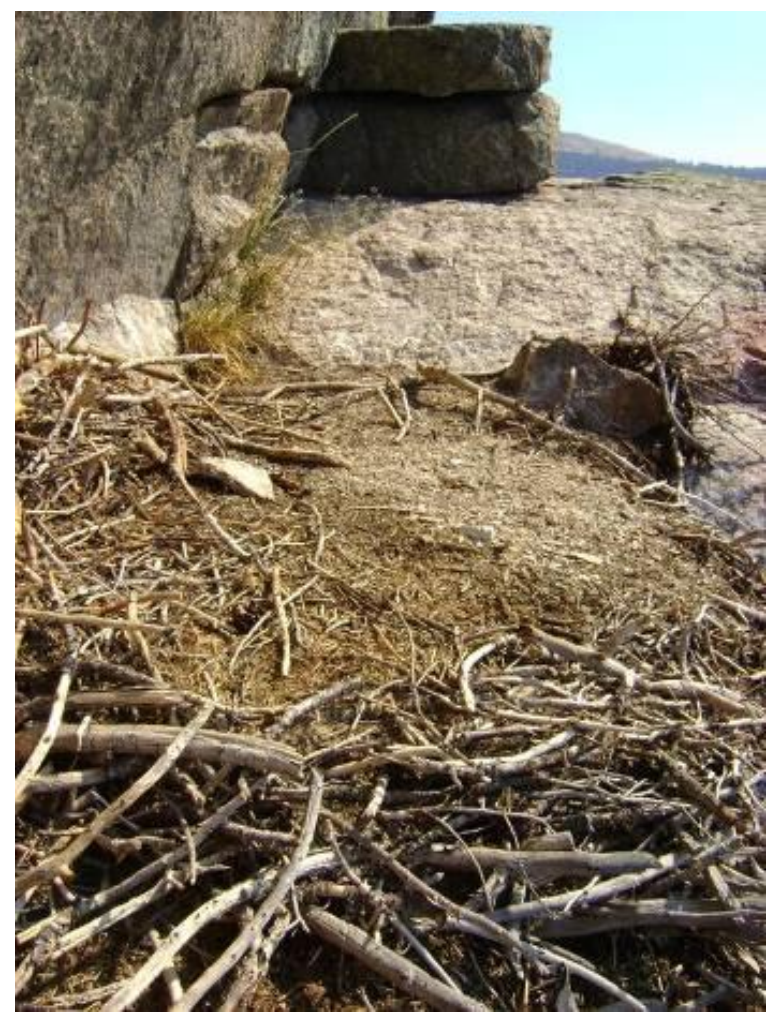

Figure 4. Peregrine Falcon nest ledge on historic Golden Eagle nest in, Yellowstone National Park

Nest ledges (Appendix Table 1) ranged in dimensions from 7.8 in $(20 \mathrm{~cm})$ wide by 10.2 in $(26$ $\mathrm{cm})$ deep to 120.8 in $(307 \mathrm{~cm})$ wide by 177.2 in $(450$ $\mathrm{cm}$ ) deep (Table 1). Nests ranged in overhead protection from open $(\mathrm{N}=1)$, slightly overhung (10$30 \%)(\mathrm{N}=3), 100 \%$ overhung (pothole) $(\mathrm{N}=2)$, to cave $(\mathrm{N}=2)$. Range of total cliff height was $70-820$ feet $(21-250 \mathrm{~m})$ tall. One 'ledge' (YNP-E-004) was on a sloping rock ledge, but was afforded a favorable nest location by being on 1.2 in $(3 \mathrm{~cm})$ of decomposed gravel which had fallen on an abandoned Golden Eagle nest.

Eight eggshell fragment samples from five nest sites were collected from the substrate of the YNP nest sites (Appendix, Table 2). No eggshell fragments were found at one site (YNP-E-008) nest site; the nest failed in 2010, and the nest had easy entry. It is postulated that the loss of eggs resulting in no eggshell fragments in the detritus may have been due to a mammalian predator entering the site. Eggshell fragment thickness from one other nest (YNP-E-004) was not available at the time of this report. At this site, Pagel dug into the decomposed gravel detritus held within the Golden Eagle stick nest to the original layer of the nest, and recovered Golden Eagle eggshell fragments. These samples were curated and will eventually be measured. Peregrine Falcon eggshell fragments from YNP did show some thinning due to, presumably, DDT/DDE; however discussion with Lloyd Kiff (The Peregrine Fund) suggested that the mean fragment thickness was not deleterious to the population (L.Kiff pers. com, Sept. 2010). At present we do not have a standard thickness for northern Rocky Mountain nest sites for comparison to achieve a "standard" eggshell thickness, as few nest ledges were entered prior to the advent or broad scale use of DDT (i.e. 1890-1945). Peregrine falcons do not build nests, but lay their eggs in a scraped nest bowl or depression in the ledge substrate (Figure 5). In general, because of the "soft" nature of the layers of nest ledge substrate at most sampled sites in YNP, thin eggshells can be incubated full term to hatch (Pagel notes).

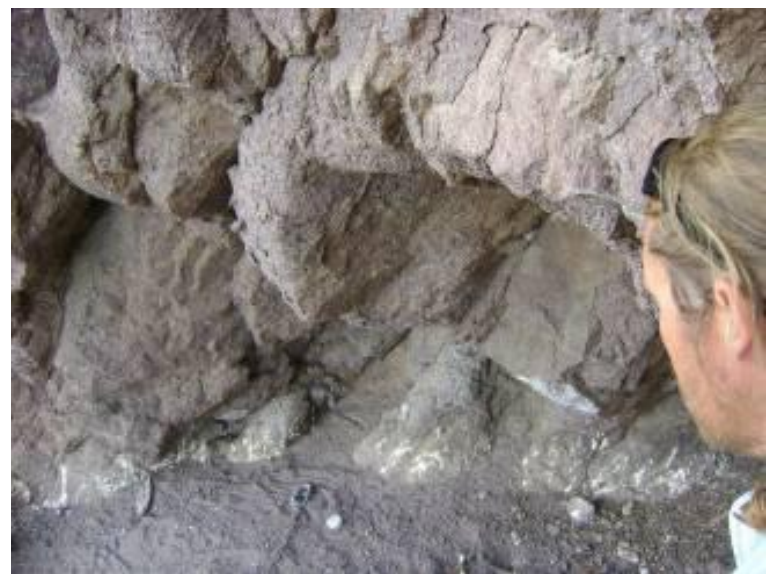

Figure 5. View into Peregrine Falcon nest ledge in Yellowstone National Park 


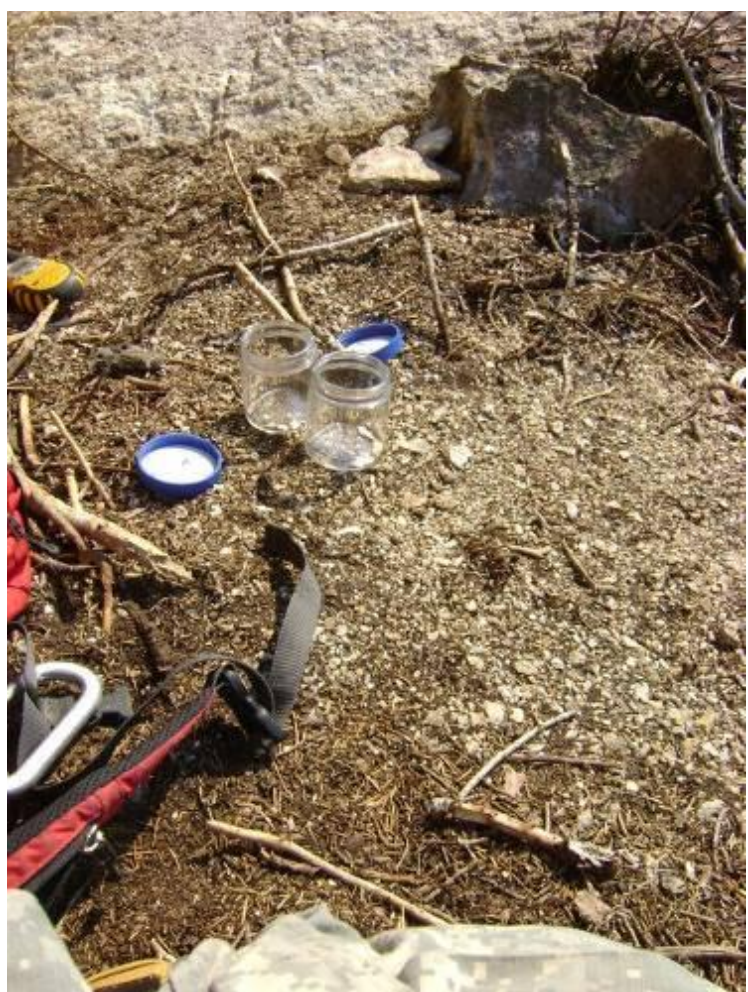

Figure 6. Eggshell fragment and prey remains collection; Peregrine Falcon nest ledge in Yellowstone National Park

The broad range of prey selected by Peregrine Falcons was reflected via samples collected from within six nest ledges (Appendix, Table 3). To date, at least 32 different species were used by Peregrine Falcons during the nest season. One site (YNP-E-004) was entered after the prey samples from other sites had been analyzed; they were curated for future analysis. Peregrine Falcon prey species ranged in size from small Pine Siskins, up to larger species such as Northern Pintail, Franklin's Gull and Pine Marten. The recovery of a Pine Marten tibia at YNP-E-001 was, to our knowledge, the first ever recorded consumption by Peregrine Falcons of this somewhat arboreal mammal. One avian predator, a male American Kestrel, was found in the prey sample at a nest in another location (YNP-E-030). American Kestrels have been found before in prey remain samples in the United States Pacific Northwest (Pagel notes). The most common prey species were Franklin's Gull and American Robin (5 nest sites each). The most unusual prey species were the Franklin's Gull, an uncommon YNP species, and the Pine Marten.

\section{$\uparrow$ Pilot RAPtor Migration SURVEy}

During September and October, 2010, pilot raptor migration surveys were conducted as part of an interagency cooperative venture between the National Park Service (Douglas Smith) and the Fish and Wildlife Service (Joel E. 'Jeep" Pagel). Migration surveys are a method to determine relative numbers of multiple species of diurnal raptors whose movement pulse passes over an established point (Bildstein 2006, Bildstein et al. 2007). Because many raptors follow distinct migratory pathways during spring and fall periods, pre-selected locations have been used, over time, to project the relative population levels of raptors (Bildstein et al. 2007, Farmer et al. 2008, Goodrich and Smith 2008). The closest extant raptor migration census locations include the following: a) Rogers Pass, Montana (est. 1988), b) Bridger Mountains, Montana (est. 1979) and c) Commissary Ridge, Wyoming (est. 2002). Past years data for each of these Montana and Wyoming sites have been collated elsewhere (Goodrich and Smith 2008).

Field survey techniques used in Hayden Valley were modeled after Cape May Raptor observation methods; now standard for hawk migration counts (Bildstein et al. 2007, HMANA 2010a). This specific technique has not been previously employed in YNP to date. The primary observation point (OP) in YP (Figure 7, 8) was located just off the road in Hayden Valley. This point was selected due to: a) the wide expanse of observation area from a single point, b) OP was away from public view, and c) the observation area affords a location where topographic and biological features were likely to be used by raptors during migration.

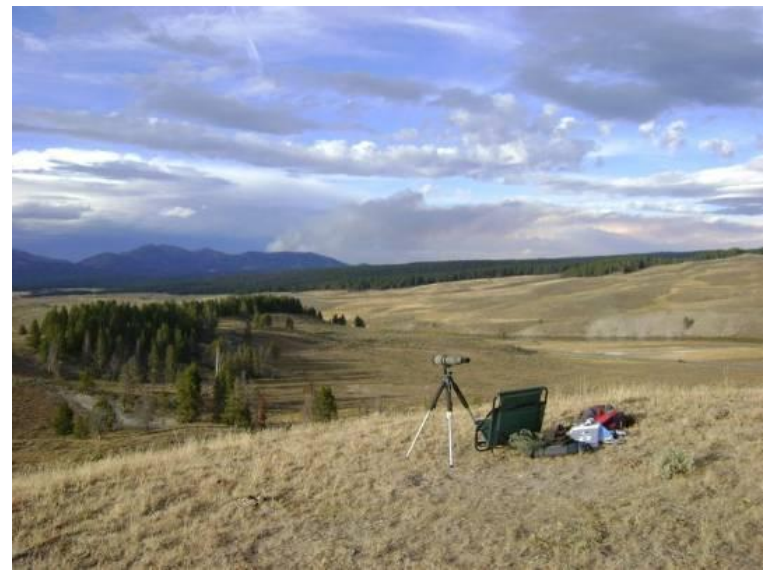

Figure 7, Raptor migration observation point, Hayden Valley in Yellowstone National Park

The 2010 field season was considered a pilot year, as limited survey time was expended. Preliminary surveys prior to establishing this point as the primary observation location were conducted by Katy Duffy (USNPS) and Pagel. Past observations of 
raptors in the mid 1990s at Mt. Washburn (YNP files) suggested that raptors may funnel through the National Park during the fall migration period. Examination of the data suggested that raptor migration through the Park may have been minimal, and was comprised mostly of Sharp-shinned Hawk, Cooper's Hawk, Red-tailed Hawk, and American Kestrel. Subsequent analysis using the location at the Hayden Valley site suggests that YNP does have a substantial migration of at least Swainson's Hawks during the fall migration. These raptors may be funneling down from the Canadian Shield and prairies through YNP on their way through to Argentina, where they are known to winter. Swainson's Hawk migration pathways have been sought by Hawk Migration Association of North America because this species, and Ferruginous Hawks "are not well sampled by the current network of sites, either because of the lack of watch sites or due to the species' dispersed migration patterns" (HMANA 2010b).

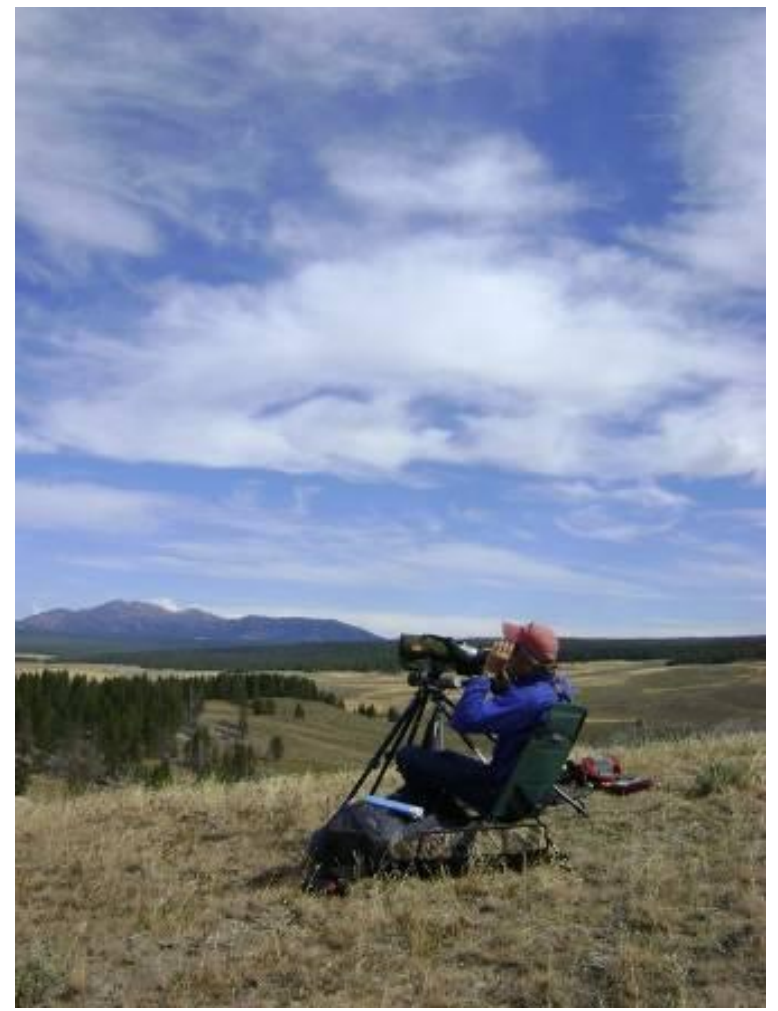

Figure 8. Dr. Douglas Smith at raptor migration observation point in Yellowstone National Park

During the pilot survey, at least 830 individual raptors were documented from the Hayden Valley site. Most of these observed raptors were Swainson's Hawks ( $N=488$ individuals). An additional $50+$ raptors were noted during this period in the park at other dispersed locations. One such sighting was during an active wildfire north of Mt. Washburn where a Red-tailed Hawk and a Swainson's Hawk were documented hunting the leading edge of the fire-line. Another sighting included a kettle of at least 25 Swainson's Hawks in the northern portion of Hayden Valley. Only one raptor was documented to have been marked; a Redtailed hawk was noted to have a satellite transmitter on it when it was observed by Pagel and staff ornithologist Lisa Baril near Tower Junction.

Raptors are known to commence fall migration per their size and latitude; smaller raptors such as American Kestrel and Sharp-shinned Hawks normally commence migration in mid to late August in the northern hemisphere. These are followed by the mid-sized raptors, such as Peregrine Falcons and Buteos such as Swainson's Hawks and Red-tailed Hawks. Later in the season, during late October and November, the larger raptors including Ferruginous Hawks, Rough-legged Hawks and eagles will migrate. The pattern shown by our data, despite the small sample size, is representative of this trend of smaller raptors migrating first (Bildstein 2006, Appendix, Table 4).

While relatively few days were expended to collect the pilot data, we believe that the data suggest YNP may be a key location to monitor long-term migratory patterns of raptors in the northern Hemisphere, as well as in the U.S. northern Rocky Mountains. Raptors moving to the east and south of Mt. Washburn via the Yellowstone River corridor appear to transect the park as they enter the Hayden Valley open habitat. The location of the observation point appears to be favorable for long term counts to assist other hawkwatch monitors assess species population status, and could complement extant migration observation locations including:

1) Rogers Pass, Montana (est. 1988)

2) Bridger Mountains, Montana (est. 1979)

3) Commissary Ridge, Wyoming (est. 2002)

Data for each of these three sites have been collated elsewhere (see Goodrich and Smith 2008)

\section{Goals}

- Evaluate the natural history components of select raptors to discern nesting, roosting, and migratory use of YNP.

- Locate territories and nest sites for Swainson's and Red-tailed hawks primarily on the northern range but also in Hayden Valley and Golden Eagles throughout YNP. 
- Opportunistically locate nest sites for other raptors species for future analysis.

- Enter raptor nest sites to collect eggshell fragments and prey remains.

- Continue with obtaining raptor sighting information from staff and park visitors. All sightings will be entered into a GIS database for later analysis.

- Expand Hayden Valley raptor migration count effort.

- Continue and expand public ranger-led programs on raptor ecology.

- Expand and update the Yellowstone raptor identification guide for use at all park visitor centers.

\section{ACKNOWLEDGEMENTS}

U.S. Fish and Wildlife Service

U.S. National Park Service

Univ. Wyoming National Park Research Station

Western Foundation of Vertebrate Zoology

René Corado and Linnea Hall, Ph.D., John Parker, N.

John Schmitt

Lloyd Kiff, and The Peregrine Fund

Yellowstone Raptor Initiative founding staff:

Douglas W. Smith, Ph.D. USNPS (DS)

Joel E. Pagel, Ph.D. $\quad$ USFWS (JP)

Katy Duffy, M.S. USNPS (KD)

Lisa Baril, M.S. USNPS (LB)

Leslie Henry USNPS (LH)

Nate Bowersock USNPS (NB)

Brenna Cassidy (BC)

Additional Cooperators to the Yellowstone Raptor Initiative:

Charles Preston Ph.D (WY)

Pete Bloom (CA)

Al Harmata Ph.D $\quad$ (MT)

Bryan Bedrosian (WY)

\section{LITERATURE CITED}

Bildstein KL. 2006. Migrating raptors of the world. Cornell Univ. Press.

Bildstein KL, Smith JP, Yosef R. 2007. Migration counts and monitoring. In: Bildstein KL, Smith E, Ruelas I, Veit RR, editors. State of North America's Birds of Prey. NuHa1 Ornithological Club and American Ornithologists Union. Series in Ornithology No. 3. Cambridge MA and Washington D.C.

Cambridge, Mass: Nuttal Ornithological Club and Washington D.C.: American Ornithologist Union.

Farmer CJ, Goodrich LJ, Inzunza ER, Smith JP. 2008. Conservation status of North America's birds of prey. In: Bildstein KL, Smith E, Ruelas I, Veit RR, editors. State of North America's Birds of Prey. NuHa1 Ornithological Club and American Ornithologists Union. Series in Ornithology No. 3. Cambridge MA and Washington D.C.

Goodrich LJ, Smith JP. 2008. Raptor migration in North America. In: Bildstein KL editor. State of North America's birds of prey. Nuttal Ornith. Club and Am. Ornith. Union.

Hawk Migration Association of North America (HMANA). 2010a. Data collection protocol. Available at http://hmana.org/data_entry_paper.php. Accessed 26 Nov. 2010.

Hawk Migration Association of North America (HMANA). 2010b. Use of hawkcount.org data for wind energy siting. Available at http://hmana.org/Hawkcount_Wind Siting.php ?PHPSESSID=23d221733b5ec31abdf2693ffa 3e4dc1. Accessed 28 Nov. 2010.

Pagel JE, Thorstrom RK. 2007. Accessing nests. In: Bird DM, Bildstein KL editors. Raptor research and management techniques. Hancock House Publ., Surry, BC.

Robinson CR. 1921. My brother Theodore Roosevelt. Scribner and Sons, New York. 


\section{APPENDIX}

Table 1. Yellowstone National Park Peregrine Falcon nest entries during the 2010 nest season. Nest entries by Joel E. Pagel, Ph.D.

\begin{tabular}{|c|c|c|c|c|c|}
\hline Nest site & Entry date & $\begin{array}{l}\text { Ledge } \\
\text { width } \\
(\mathbf{c m}) \\
\end{array}$ & $\begin{array}{l}\text { Ledge } \\
\text { depth } \\
(\mathrm{cm})\end{array}$ & Ledge type & $\begin{array}{l}\text { Peregrine Falcons present } \\
\text { during entry }\end{array}$ \\
\hline YNP-E-004 & 02 Aug. 2010 & \multicolumn{3}{|c|}{ Ledge not accessed due to rope length } & Adult female. \\
\hline YNP-E-004 & 17 Sept. 2010 & 139 & 115 & $\begin{array}{l}\text { Ledge; abandoned } \\
\text { Golden Eagle nest; } 10 \% \\
\text { overhang }\end{array}$ & $\begin{array}{l}\text { None; Adult and subadult } \\
\text { Golden Eagle. }\end{array}$ \\
\hline YNP-E-015 & 03 Aug. 2010 & 43 & 26 & pothole; $100 \%$ overhung & $\begin{array}{l}\text { Adult female; at least } 1 \text { female } \\
\text { fledgling }\end{array}$ \\
\hline YNP-E-001 & 04 Aug. 2010 & 214 & 161 & cave & $\begin{array}{l}\text { Adult female; } 2 \text { male and at least } \\
1 \text { (possibly 2) unknown sex } \\
\text { fledglings. }\end{array}$ \\
\hline YNP-E-007 & 04 Aug. 2010 & 307 & 450 & cave & $\begin{array}{l}\text { Adult female; at least } 2 \text { female } \\
\text { fledglings }\end{array}$ \\
\hline YNP-E-008 & 05 Aug. 2010 & 164 & 60 & pothole; $100 \%$ overhung & Adult female and male \\
\hline $\begin{array}{l}\text { YNP-E-020 } \\
2009 \text { ledge }\end{array}$ & $\begin{array}{l}\text { 05 Aug. } 2010 \\
\text { and } 17 \text { Sept. } \\
2010\end{array}$ & 20 & 26 & ledge; $0 \%$ overhang & Adult present; unknown sex \\
\hline $\begin{array}{l}\text { YNP-E-020 } \\
2010 \text { ledge }\end{array}$ & 05 Aug. 2010 & 240 & 60 & ledge; $30 \%$ overhang & Adult present; unknown sex \\
\hline YNP-E-030 & 06 Aug. 2010 & 74 & 70 & ledge; $10 \%$ overhang & none \\
\hline
\end{tabular}

Table 2. Yellowstone National Park Peregrine Falcon eggshell fragment thicknesses from samples collected during the 2010 nest season. Nest entries by Joel E. Pagel, Ph.D. Samples measured using digital gauge (no tapping) by René Corado; all fragments curated at Western Foundation of Vertebrate Zoology, Camarillo, CA.

\begin{tabular}{|l|c|c|c|c|}
\hline \multicolumn{1}{|c|}{ Nest site } & Entry date & $\begin{array}{c}\text { Mean } \\
\text { Eggshell } \\
\text { Thickness } \\
\text { (mm) }\end{array}$ & $\begin{array}{c}\text { Mean Eggshell } \\
\text { Thickness with } \\
\text { Membrane (mm)* }\end{array}$ & $\begin{array}{c}\text { Range of Eggshell } \\
\text { Fragment } \\
\text { Thicknesses } \\
\text { Recovered (mm) }\end{array}$ \\
\hline (YNP-E-015) & 03 Aug. 2010 & 0.281 & 0.357 & $0.250-0.309$ \\
\hline (YNP-E-001) 2010 (fragments) & 04 Aug. 2010 & 0.253 & 0.329 & $0.230-0.287$ \\
\hline $\begin{array}{l}\text { (YNP-E-001) 2010 (1/2 egg) } \\
\text { (YNP-E-007) } \\
\text { (pre 2010) }\end{array}$ & 04 Aug. 2010 & 0.268 & 0.344 & $0.294-0.238$ \\
\hline $\begin{array}{l}\text { (YNP-E-007) } \\
\text { (2010) }\end{array}$ & 04 Aug. 2010 & 0.26 & 0.336 & $0.247-0.285$ \\
\hline $\begin{array}{l}\text { (YNP-E-020) } \\
\text { (2009 ledge) }\end{array}$ & 04 Aug. 2010 & 0.265 & 0.341 & $0.256-0.280$ \\
\hline $\begin{array}{l}\text { (YNP-E-020) (2010 ledge) } \\
\text { (YNP-E-008) }\end{array}$ & 05 Aug. 2010 & 0.278 & 0.354 & $0.166-0.378$ \\
\hline (YNP-E-030) & 05 Aug. 2010 & & 0.322 & $0.298-0.278$ \\
\hline (YNP-E-004) & 06 Aug. 2010 & 0.274 & No fragments recovered \\
\hline
\end{tabular}

*Membrane thickness from Yellowstone National Park samples were measured to be $0.076 \mathrm{~mm}$.

** Golden Eagle eggshell fragments laid prior to the use of the site by Peregrine Falcons were also recovered from this nest ledge. 
APPENDIX (continued)

Table 3. Yellowstone National Park Peregrine Falcon prey remain analysis from samples collected during the 2010 nest season. Nest entries by Joel E. Pagel, Ph.D., prey analysis by N. John Schmitt.

\begin{tabular}{|c|c|c|c|c|c|c|c|c|}
\hline Species & 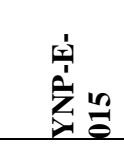 & $\frac{1}{\dot{1}} \overline{8}$ & 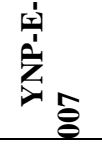 & 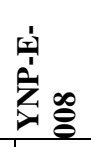 & 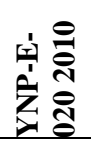 & 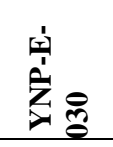 & 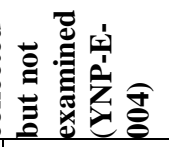 & 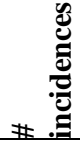 \\
\hline Northern Pintail & & & 1 male & & & & - & 1 \\
\hline American Kestrel & & & & & & 1 male & - & 1 \\
\hline Killdeer & & & & & 1 & & - & 1 \\
\hline Yellow-legs spp. $^{2}$ & & & 1 & & & & - & 1 \\
\hline Shorebird spp. ${ }^{3}$ & & & & & 1 & & - & 1 \\
\hline Shorebird spp. ${ }^{4}$ & & & & & 1 & & - & 1 \\
\hline Godwit & & 1 & & & & & - & 1 \\
\hline Dowitcher spp. & 1 & & & & & & - & 1 \\
\hline Wilson's Phalarope & & 2 & 1 & & & & - & 2 \\
\hline Northern Phalarope & & 2 & & & & & - & 1 \\
\hline Franklin's Gull & $1 \mathrm{imm}$. & 1 juv \& 1 ad. & 1 & 1 & & $1 \mathrm{imm}$. & - & 5 \\
\hline Three-toed Woodpecker & & 1 & & & & & - & 1 \\
\hline Northern Flicker & & & & 1 & & & - & 1 \\
\hline Woodpecker spp. ${ }^{5}$ & 1 & & & & & & - & 1 \\
\hline Woodpecker spp. ${ }^{6}$ & & 1 & & & & & - & 1 \\
\hline Eastern Kingbird & & 1 & & & 1 & & - & 2 \\
\hline Kingbird spp. $^{7}$ & & & & & & 1 & - & 1 \\
\hline Clark's Nutcracker & & 1 & & 1 & & & - & 2 \\
\hline Horned Lark & & 1 & & & & & - & 1 \\
\hline Mountain Bluebird & & 1 & & & & 1 & - & 2 \\
\hline Barn Swallow & & 1 & 1 & & & & - & 2 \\
\hline Swallow spp. & & & & & 1 & & - & 1 \\
\hline Townsend's Solitaire & & 1 & & & & & - & 1 \\
\hline American Robin & 1 & 1 & 1 & 1 & & 1 & - & 5 \\
\hline Thrush spp. $^{8}$ & & 1 & & & & & - & 1 \\
\hline Western Meadowlark & & & & 1 & & 1 & - & 2 \\
\hline Red-winged Blackbird & & 1 & & & 1 & & - & 2 \\
\hline Brewer's Blackbird & & & 1 & & & & - & 1 \\
\hline Common Grackle & & & & & & 1 & - & 1 \\
\hline${ }_{9}^{\text {Carpodacus spp. (Finch) }}$ & & & & & 1 & & - & 1 \\
\hline Red-crossbill & & 1 & 1 & & & & - & 2 \\
\hline Pine Siskin & & 1 & & & & & - & 1 \\
\hline Fish spp. $^{10}$ & & 2 & & & & & - & 1 \\
\hline Pine Martin ${ }^{11}$ & & 1 & & & & & - & 1 \\
\hline
\end{tabular}

\footnotetext{
${ }^{2}$ Possibly Lesser Yellow-legs

${ }^{3}$ Western Sandpiper size

${ }^{4}$ Dowitcher size

${ }^{5}$ Either Williamson's Sapsucker female or Three-toed Woodpecker

${ }^{6}$ Possibly Hairy Woodpecker

${ }^{7}$ Western or Eastern Kingbird

${ }^{8}$ Hermit or Swainson's Thrush

${ }^{9}$ Possibly Cassin's Finch

${ }^{10}$ Represented by 2 sets of pelvic fins

${ }^{11}$ Represented by one foot with attached tibia
} 
APPENDIX (continued)

Table 4. Results of pilot 2010 raptor migration observations from Hayden Valley, Yellowstone National Park.

\begin{tabular}{|c|c|c|c|c|c|c|c|c|c|c|c|}
\hline Species & $\begin{array}{c}13 \\
\text { Sept. } \\
2010 \\
\end{array}$ & $\begin{array}{c}14 \\
\text { Sept. } \\
2010 \\
\end{array}$ & $\begin{array}{c}15 \\
\text { Sept. } \\
2010 \\
\end{array}$ & $\begin{array}{c}16 \\
\text { Sept. } \\
2010 \\
\end{array}$ & $\begin{array}{c}17 \\
\text { Sept. } \\
2010 \\
\end{array}$ & $\begin{array}{c}18 \\
\text { Sept. } \\
2010 \\
\end{array}$ & $\begin{array}{c}02 \\
\text { Oct. } \\
2010 \\
\end{array}$ & $\begin{array}{c}\mathbf{0 3} \\
\text { Oct. } \\
2010 \\
\end{array}$ & $\begin{array}{c}09 \\
\text { Oct. } \\
2010 \\
\end{array}$ & $\begin{array}{c}15 \\
\text { Oct. } \\
2010 \\
\end{array}$ & $\begin{array}{c}\text { Species } \\
\text { total }\end{array}$ \\
\hline $\begin{array}{l}\text { Red-tailed } \\
\text { Hawk }\end{array}$ & 7 & 11 & 11 & 6 & 2 & 32 & 23 & 22 & 49 & 11 & 174 \\
\hline $\begin{array}{l}\text { Swainson's } \\
\text { Hawk }\end{array}$ & 10 & 21 & 97 & 59 & 66 & 235 & & & & & 488 \\
\hline $\begin{array}{l}\text { Ferruginous } \\
\text { Hawk }\end{array}$ & & 2 & & & & 1 & & 1 & 2 & 1 & 7 \\
\hline $\begin{array}{l}\text { Rough-legged } \\
\text { Hawk }\end{array}$ & & & & & & & & & & 7 & 7 \\
\hline $\begin{array}{l}\text { Unidentified } \\
\text { Buteo }\end{array}$ & 6 & 12 & 32 & 7 & 9 & 10 & & & & & 76 \\
\hline Golden Eagle & & & & & & & & 1 & 8 & & 9 \\
\hline Bald Eagle & & & 1 & 1 & & 1 & 1 & 2 & 2 & & 8 \\
\hline $\begin{array}{l}\text { Unidentified } \\
\text { Eagle }\end{array}$ & & & & 1 & & 1 & & & & & 2 \\
\hline $\begin{array}{l}\text { Sharp-shinned } \\
\text { Hawk }\end{array}$ & & & & & & & 2 & & & 1 & 3 \\
\hline Cooper's Hawk & & & 6 & 2 & & 5 & 1 & & 2 & & 16 \\
\hline $\begin{array}{l}\text { Northern } \\
\text { Goshawk }\end{array}$ & & & 1 & & & & & & & & 1 \\
\hline $\begin{array}{l}\text { Unidentified } \\
\text { Accipiter }\end{array}$ & & & 2 & 1 & & 2 & & & & & 5 \\
\hline Osprey & & & & & & & & & & & 0 \\
\hline $\begin{array}{l}\text { Northern } \\
\text { Harrier }\end{array}$ & 1 & & & & 1 & 4 & & 1 & 5 & & 12 \\
\hline $\begin{array}{l}\text { American } \\
\text { Kestrel }\end{array}$ & & & 7 & 3 & & 1 & & & & & 11 \\
\hline Prairie Falcon & & & 1 & & & & & & & & 1 \\
\hline $\begin{array}{l}\text { Peregrine } \\
\text { Falcon } \\
\end{array}$ & 1 & & & & & & & & & & 1 \\
\hline $\begin{array}{l}\text { Unidentified } \\
\text { Falcon }\end{array}$ & & & & 1 & & & 1 & & & & 2 \\
\hline $\begin{array}{l}\text { Unidentified } \\
\text { Small Raptor }\end{array}$ & 1 & & & & & & & & & & 1 \\
\hline $\begin{array}{l}\text { Unidentified } \\
\text { Raptor }\end{array}$ & & & & 1 & & 2 & 2 & & 1 & & 6 \\
\hline Total & 26 & 46 & 158 & 82 & 78 & 294 & 30 & 27 & 69 & 20 & 830 \\
\hline Time & $\begin{array}{c}1600- \\
1750 \\
\end{array}$ & $\begin{array}{c}1600- \\
1750 \\
\end{array}$ & $\begin{array}{c}1030- \\
1230 \\
\end{array}$ & $\begin{array}{c}1005- \\
1215 \\
\end{array}$ & $\begin{array}{c}1615- \\
1845 \\
\end{array}$ & $\begin{array}{c}1000- \\
1900 \\
\end{array}$ & $\begin{array}{c}1020- \\
1500\end{array}$ & $\begin{array}{c}1130- \\
1615 \\
\end{array}$ & $\begin{array}{l}1107- \\
1540 \\
\end{array}$ & $\begin{array}{l}1100- \\
1500 \\
\end{array}$ & \\
\hline Observers & KD, JP & JP & LB, JP & JP, DS & JP & JP, BP & $\mathrm{KD}$ & $\mathrm{KD}$ & KD & $\mathrm{KD}$ & $\begin{array}{c}\text { LB, } \\
\text { KD, } \\
\text { JP, BP, } \\
\text { DS }\end{array}$ \\
\hline
\end{tabular}

